\title{
Multisystem Resilience for Children and Youth in Disaster: Reflections in the Context of COVID-19
}

\author{
Ann S. Masten ${ }^{1}$ (D) . Frosso Motti-Stefanidi ${ }^{2}$ \\ Published online: 25 June 2020 \\ (C) Springer Nature Switzerland AG 2020
}

\begin{abstract}
In the context of rising disasters worldwide and the challenges of the COVID-19 pandemic, this commentary considers the implications of findings in resilience science on children and youth for disaster preparation and response. The multisystem challenges posed by disasters are illustrated by the COVID-19 pandemic. We discuss the significance of disasters in the history of resilience science and the emergence of a unifying systems definition of resilience. Principles of a multisystem perspective on resilience and major findings on what matters for young people in disasters are delineated with reference to the pandemic. Striking parallels are noted in the psychosocial resilience factors identified at the level of individual children, families, schools, and communities. These parallels suggest that adaptive capacities associated with resilience in these interacting systems reflect interconnected networks and processes that co-evolved and may operate in concert. As resilience science moves toward integrated theory, knowledge, and applications in practice, particularly in disaster risk reduction and resilience promotion, more focus will be needed on multisystem and multidisciplinary research, communication, training, and planning.
\end{abstract}

Keywords Resilience $\cdot$ Disaster $\cdot$ Multisystem $\cdot$ COVID-19 $\cdot$ Pandemic

As the frequency of major disasters rises and the world confronts a life-threatening pandemic, resilience investigators are asked to contribute their knowledge and perspectives to help communities and societies prepare and respond more effectively. In response to this call to action, the purpose of this commentary is to consider strategies for promoting resilience in children and youth in the context of the developmental science on disasters, applying two lenses: (1) a resilience framework based on decades of resilience science and (2) observations of the challenges posed by an unfolding pandemic. We begin by highlighting the multisystem threats posed by the COVID-19 disaster. Then, we discuss the significance of disaster in the history of resilience science and the emerging consensus in support of a systems definition of resilience. Principles of a systems approach to resilience are delineated briefly along with the concept of negative and positive cascades in disaster. General findings from the research on "what

Ann S. Masten

amasten@umn.edu

1 University of Minnesota Twin Cities, Minneapolis, MN, USA

2 National and Kapodistrian University of Athens, Athens, Greece matters" for resilience of children in disasters are highlighted with illustrative reference to COVID-19. Striking parallels are noted in resilience factors observed across systems at the level of children, families, schools, and communities. Implications of a multisystem resilience perspective for action to promote the resilience of children and youth are described, both generally, in preparation or response to disaster and, more specifically, in consideration of COVID-19.

Definitions of disaster vary, although most definitions include the core idea of circumstances that cause large-scale disruption threatening the lives of many people. Some research on disaster in child development is focused only on natural disasters (e.g., hurricane and earthquake) or technological disasters (oil spill) or blends of these categories, as happened during Hurricane Katrina when levees collapsed or after the 2011 earthquake/tsunami in Japan and resulting meltdown of Fukushima (Osofsky \& Osofsky, 2018). Some reviews include these disasters plus terror attacks (e.g., 9-11) that share the features of sudden onset and large-scale damage, but exclude war (e.g., Furr et al., 2010). Other reviews include diverse adversities that affect large populations with lifethreatening potential harm, including pandemics, war and terror, and natural disasters. Efforts to distill knowledge from research on the effects of disaster on child development 
frequently include wide-ranging types of mass-trauma experiences because the nature of risks and responses mobilized by disasters for children are similar, as are the strategies implicated for supporting child well-being in the context of such threats (e.g., Danese et al., 2020; Masten \& Narayan, 2012; Masten \& Osofsky, 2010; Masten et al., 2015; Peek et al., 2018). In alignment with a broad perspective, we adopted the following definition of disaster proposed by Aldrich (2012): "an event that suspends normal activities and threatens or causes severe, communitywide damage" (p. 3). For purposes of this commentary, historical trauma and related intergenerational adversities associated with oppression and racism, which represent profound threats to human development (Comas-Diaz et al., 2019), are discussed primarily as moderators of risks and harm from COVID-19.

\section{COVID-19: A Multisystem Disaster}

Pandemics, including COVID-19, are disasters with enormous impact. This pandemic has upended the lives of people in communities across the world, with huge and mounting costs measured in human lives and economic damage, as well as altered hopes and dreams. As a multisystem, cascading disaster, it calls for multisystem responses and coordinated integration of the best science we have for application to solutions (Yoshikawa et al., 2020). In this commentary, we focus on the needs of children in an effort to glean guidance from resilience science that has focused on children.

COVID-19 poses a global threat as the novel coronavirus spreads across the world. This pandemic is causing not only dangerous infections at the individual level but also disrupting the operations of virtually all systems essential to human life and desirable for human well-being, including family life, healthcare, work, education, economies and financial operations, transportation, manufacturing, emergency and other social services, recreation, and the functioning of governments from the local to national level, global institutions such as the United Nations or World Bank, and humanitarian agencies that operate around the world. Risks to human life span all of these levels and the challenges continue to change as the pandemic unfolds. Concomitantly, responses to the virus are mobilized at multiple levels as systems respond to the disruptions and threats posed by the pathogen.

The pandemic poses many challenges to children and their families. Individual children, as well as their family members and friends, face the reality and the fears of separation and loss and all of the grief and hardships that may follow. At the individual level, the virus challenges survival directly through infection and illness, stimulating a complex response of biological systems that respond to such challenges. Individuals are more or less vulnerable to the infection, depending on many factors, including their age, general health, and how well their immune system is currently working. Some of these vulnerabilities, for example, those related to age or underlying health conditions, were noted quickly and others remain unknown as of yet. When individual responses to infection are not adequate for recovery, medical intervention is necessary for survival and then the quality of resources and access to quality interventions are crucial. That access can depend on many factors, including inequality as well as a healthcare system that has exceeded its capacity to care for new patients.

A child's or parent's survival may require the best medical care and services that a healthcare system can offer at a time when there is tremendous pressure on medical services. Access to essential medical treatment is influenced not only by supply and demand but also by historical discrimination, poverty, and marginalization. In the USA, COVID-19 is exposing life-threatening racial/ethnic disparities in vulnerability to severe illness and death, as well as in access to healthcare (Webb Hooper et al., 2020).

Efforts at multiple system levels can be directed at preventing exposure to COVID-19 infection and these efforts can be observed around the world. Individuals can play a role in self-protection or in protecting other individuals through social distancing, handwashing, and similar measures. Parents play a role by teaching and monitoring these behaviors in their children. If and when a vaccine becomes available, individuals can participate or have their children vaccinated. However, reaching the scale of vaccination required to achieve the public safety goal of herd immunity (Metcalf et al., 2015) is likely to require an all-out multisystem effort led by governments and healthcare officials at many levels, including Federal and State agencies as well as global nongovernmental organizations (NGOs) with health expertise, such as the World Health Organization. Leaders in many systems, ranging from schools to religious organizations and governments, can take steps to enforce or support preventive efforts in words and actions by following and modeling social distancing guidelines; closing schools, parks, or restaurants, places of worship, state or national borders; and enforcing quarantines.

Challenges also include adjusting to the consequences of the pandemic on day-to-day life and handling the fear and uncertainty of an unexpected shock, again at multiple levels. The lives of children and youth to date have been disrupted in multiple ways as efforts to contain the novel coronavirus required schools, childcare centers, colleges, recreation centers, libraries, entertainment centers, and many other venues to close down. Play is restricted in many ways and older children are physically separated from their friends and restricted from doing most of the social activities they enjoy, although social media offers some alternatives.

There are also numerous indirect effects of the pandemic on children. Already there is evidence of families postponing regular pediatric health visits and routine vaccines that 
jeopardize healthy development. Humanitarian agencies and NGOs that provide crucial life-saving programs around the world in support of healthy child development are hampered by travel restrictions, closed borders, and supply shortages. Lost jobs and wages affect the ability of families to provide the basic necessities for their children. Parents and other caregivers who are the key protective factors in the lives of children, buffering them against adversity, may be overwhelmed by the added stresses of their situation.

Parents and caregivers of children are required to contend with all the usual challenges of parenting plus the many tasks of keeping their children safe and mentally healthy during a time of collective danger and stress, often juggling work responsibilities. Some heads of household are required to keep working in hazardous positions that expose themselves and their families to the virus as well as high levels of stress. Others lose their jobs and must deal with the challenges of securing food, housing, and other necessities for their children and any other dependent family members. Government leaders, concomitantly, face the challenges of reassuring their populations while ensuring that there are adequate emergency services, food, communication channels, hospital surge capacity, and other community, state, or national necessities.

As the pandemic continues and cascading consequences compound, such as an extended economic recession or depression, cumulative effects of stress and isolation can be expected to grow, and new challenges can emerge. Children and parents alike may become frustrated, bored, depressed, or irritable. In the worst situations, family violence, suicide, or child maltreatment can occur (Catani et al., 2008; Reifels et al., 2018; Seddighi et al., 2019; Yoshikawa et al., 2020). With recovery and the resumption of school, work, and other aspects of normal or "new normal" life, there may be concerns about new outbreaks, changes required in daily life, or missed opportunities.

Despite these many challenges, which can seem overwhelming, research on human resilience provides hope about the eventual outcomes of most children and families in the wake of this pandemic. Research on how children fare in the aftermath of disasters offers compelling evidence of resilience as well as disaster and trauma effects, with clues to what makes a difference for the well-being of children.

\section{Disaster in the History of Resilience Science}

Disasters have played a salient role in the origins and evolution of the research on resilience in children (Masten, 2014a). The devastation wrought by World War II led clinicians and researchers concerned with the welfare of children to study the effects of traumatic war experiences on children (Freud \& Burlingham, 1943; Despert, 1944; Garmezy, 1983). Subsequently, research on isolated catastrophes affecting children began to delineate the effects of acute onset, unexpected mass-trauma events on children. These included the Aberfan disaster of 1966 in Wales, when multiple slag "tips" from mining were loosened by heavy rain and rushed into the town of Aberfan, burying the elementary school and leaving 116 children and 28 adults dead (Lacey, 1972). The eerily similar Buffalo Creek disaster in 1972 killed 125 people in a small community when a coal-slurry dam collapsed in heavy rain, sending a wall of water, mud, and debris into the valley below (Erikson, 1976; Gleser et al., 1981). A resulting lawsuit against the coal company documented effects on surviving children and adults, with a 17-year follow-up of the children producing one of the first longitudinal studies of a major disaster on child development (Korol et al., 2002).

Data from Buffalo Creek highlighted a number of findings that would be replicated in later disaster research. There were dose effects showing worse adjustment associated with greater exposure to destruction and death, a range of mental health symptoms, and notable age and sex differences. Girls showed more internalizing symptoms and less externalizing problems than boys. Regressive behaviors were common among the younger children, although older children generally showed more post-traumatic stress and other psychiatric symptoms. Better family functioning in the aftermath of the disaster was related to child well-being. After 17 years, some symptoms (particularly post-traumatic stress) lingered in the child survivors, but many of these traumatized young people were doing okay. Korol et al. (2002) concluded that most had recovered by adulthood, with no more symptoms than a comparison group, with the caveat that some of the most affected children may have been lost to follow-up.

Research on many other disasters has documented broad effects of disasters on children, discussed further below. These include studies of storms (e.g., tornadoes and hurricanes), floods, ferry or boat accidents, earthquakes, tsunamis, nuclear accidents, terror attacks (e.g., Oklahoma City, 9-11), wildfires, pandemics (e.g., HIV and H1N1), and oil spills, as well as political violence (La Greca and Silverman, 2009; Masten et al., 2015).

It was not long after the idea of resilience emerged in the literature on risk for psychopathology (around 1970) that the variation in responses of children to disasters was folded into this emerging science (e.g., Garmezy, 1983). Now there is a diverse and growing literature on resilience in the context of different kinds of disasters (Danese et al., 2020; Fothergill, 2017; Masten et al., 2015; Peek et al. 2018).

In light of the present global pandemic, research on risk and resilience of children affected by the HIV/AIDS pandemic may be particularly relevant. Caused by a retrovirus (the human immunodeficiency virus; HIV), this pandemic was recognized in 1981 and it has continued to confront the world 
with evolving challenges. By 2018, according to data reported by the The Joint United Nations Programme on HIV/AIDS (UNAIDS, 2019), 75 million people had been infected with HIV and 32 million individuals had died. The toll of HIV includes millions of children who have become infected, died, or orphaned as HIV/AIDS ravaged regions of the world, such as sub-Saharan Africa. When treatments improved with antiretroviral therapy, death rates fell dramatically, but many individuals still live with the disease and it continues to spread. Now the health of individuals with HIV/AIDS is further threatened by COVID-19, both because of their underlying vulnerability to infection and also because the new pandemic threatens to disrupt access to essential treatments.

The U.S. President's Emergency Plan for AIDS Relief (PEPFAR), initiated by President George W. Bush in 2003, has provided billions of dollars annually to combat the HIV pandemic, the largest investment in a single disease by any government in history, although it appears likely that the global COVID-19 response will eclipse this effort. PEPFAR has had enormous successes in the fight against this retrovirus, saving many lives (Fauci and Eisinger, 2018).

Initially, research on the impact of HIV/AIDS on children was focused on the many risks of contracting the illness and the toll it was taking in the lives of children. Hazards for children included infection and related developmental problems, illness and death of caregivers, domestic violence, family separations, community stigma, disrupted education, and other related issues (Betancourt et al., 2013; Sherr et al., 2014, 2016). In a systematic review of the literature on mental health and resilience in HIV-affected children, Betancourt and her colleagues (2013) found few studies focused on resilience. However, the limited data implicated protective factors at multiple system levels, including educational resources, social support from the community, positive parenting or generally well-functioning families, and, in the young people themselves, optimism and active coping. In the time since Betancourt et al. (2013) called for more research on resilience among children affected by HIV/AIDS, research has expanded to focus more on social protections and strength-focused interventions for children and adolescents whose health and well-being are jeopardized by HIV. Moreover, as the death rate from HIV infection decreased, there also has been a notable change in goals for children, from surviving to thriving (e.g., Sayward et al., 2019).

Throughout the ongoing history of resilience science, studies of children and youth confronting diverse threats, including disasters, have matured and changed (Masten \& Cicchetti, 2016). Resilience science has embraced new technologies and statistical approaches that have made it possible to conduct more research in the field, uploading data remotely, for example, and to study resilience at multiple levels of analysis, including brain function. Definitions of resilience have changed over time as well.

\section{Resilience Defined as a Systems Concept}

From early in resilience science history, there has been controversy and confusion about the definition of the core construct (Kalisch et al., 2019; Masten \& Cicchetti, 2016). Nonetheless, there is a growing consensus that resilience is best defined as a systems concept referring to the successful adaptation of a complex dynamic system to threats or disturbances, drawing on distributed capacity through many processes. In recent publications, the first author (e.g., Masten, 2018a) has defined resilience as the capacity of a dynamic system to adapt successfully to challenges that threaten the function, survival, or development of the system. As a system responds to challenge, what we observe is the ongoing result of many processes by which a system's adaptive capacities, often distributed in networks of interconnected systems, are engaged to restore equilibrium or transform the system so it can continue on with its life and development. We observe the adaptive pathway that emerges from the engagement of multisystem adaptive capacity to meet a challenge or series of challenges. In a classic paper on community resilience to disasters, Norris et al. (2008) defined resilience as a process linking a set of adaptive capacities to a positive trajectory of functioning and adaptation after a disturbance (p. 130).

In our view, there is a compelling rationale for adopting a systems definition of resilience in disasters that is broad enough to integrate resilience research across disciplines but also narrow enough to be meaningful. Disasters are quintessentially multisystemic in nature. It is essential to define resilience to encompass theories and empirical findings across system levels and disciplines, spanning ecology as well as the social and biological sciences, because disasters are multisystem events.

When the system of focus is a living human individual, a systems definition of resilience parallels the integrated systems perspective on development that emerged in recent decades to become the leading metatheory in developmental science (Bronfenbrenner \& Morris, 2006; Gottlieb, 2007; Lerner, 2006; Masten \& Cicchetti, 2016; Overton, 2013; Zelazo, 2013). The developmental systems approach to resilience that evolved, particularly in studies of risk and resilience in children, aligns well with systems theory in family social science (Becvar, 2013; Walsh, 2016). Until recently, surprisingly, little effort was made to integrate the individual-focused and family-focused theory and research on resilience. Now there is a concerted effort to bring these fields of research together in a multisystem approach (Harrist et al., 2019; Masten \& Monn, 2015; Masten, 2018a; Henry et al., 2015).

Similarly, there is a growing effort to integrate the study of resilience as it has evolved in the context of other systems important to children and families, most notably schools and communities. Schools, like families, play a critical role in both protecting children from present dangers and nurturing their 
future resilience, through education and socialization (Lai et al., 2016; Masten, 2018b; Masten \& Motti-Stefanidi, 2009; Masten et al., 2019; Ungar et al., 2019). Communities support children and families in many ways as well, through after-school and summer activities, libraries, emergency services, and numerous other services. Just as children depend on families for resilience, families depend on communities (Norris et al., 20,008).

\section{Principles of a Systems Approach to Human Resilience}

Adopting a systems approach to resilience has a number of implications. In this section, we briefly describe core principles of a systems perspective on resilience. Given the goal of a more unified resilience science, we define these broadly, in the hope they may apply to systems at an individual, family, or community level. These principles are adapted in part from those proposed by Masten \& Cicchetti (2016) for individuals.

- Human adaptation and development at the individual or social level arises from the interactions of many processes and systems across levels of function, ranging from molecular levels within individuals (e.g., epigenetic and immune system processes) to other social levels involving families, friends, and colleagues, to interactions at the community level (e.g., schools, emergency service systems) or involving more distal macrosystems (e.g., government) that influence the lives of individuals, families, or communities indirectly through policies. Many systems must be engaged in effective planning for and responding to a pandemic.

- Resilience is distributed across systems and relationships that can be mobilized to respond to challenges and thus resilience should not be viewed as a singular, isolated trait of a person, family, or community, but rather as a broader and multifaceted capacity. The capacity for combatting this pandemic extends across many systems.

- Resilience is dynamic, changing as circumstances and systems change as a result of many interactions within and between systems. Just as immune systems of individuals fluctuate over time, the resilience of a community or nation to threats of a pandemic will also fluctuate.

- Resilience for a given system and situation in time can surge through activation or added resources and be depleted in response to demands on capacity. Hospital capacity for handling cases of COVID-19 that require intensive care or ventilators is finite and it will vary as a function of resources, personnel availability and function, and incoming supplies of personnel and equipment.

- Resilience capacity also changes (increasing or decreasing) as a function of development as the system (individual, family, or community) acquires higher level functions, learns from experience, and eventually-in the case of living individuals - declines. Older children and adults have more capacity than a young infant does for social distancing and other protective actions, as well as enlisting help when they need it. However, an elderly individual with less functional immune capacity has less resilience capacity than a younger person with similar social and economic resources and a more robust immune system. Similarly, communities that have experience with successful efforts to stem the spread of a pandemic will have more capacity to stem another wave.

- The resilience of an individual, family, or community for one kind of challenge may differ from that same system's resilience with respect to another kind of challenge. Thus, an individual or a nation that has shown remarkable resilience to one kind of threat, such as an economic challenge, can suffer calamity in the face of a pandemic.

- Resilience can cascade or spread over time by multiple processes, across systems, from one systems level to another, or one generation to another. Infections notoriously cascade but so do adaptive processes to curtail their effects, as described further below.

In the situation of an individual child or adult and COVID19 infection, risk and resilience before, during, and after infection will depend on many processes within the individual related to health status and immune function, but also the financial and social situation of that individual, the nature of the person's work, school, or living situation, and many aspects of the community, including density and medical surge capacity. Similarly, the resilience of a family will depend on multiple aspects of individual resilience within the family, supports from other families, and many aspects of community support for families and individuals. Communities, in turn, will depend on the resilience of state and national governments and NGOs that may offer resources and emergency surge protection. As a pandemic unfolds, the threats posed to individuals, families, and communities will be changing continually as systems are challenged, restored, or depleted, and as additional help arrives.

\section{Developmental Cascades}

A key implication of a systems view of resilience stems from the salient role of interactions in shaping adaptive function over time. Interactions related to risk and resilience processes can have cascading consequences, spreading negative or positive effects across domains, levels, and even generations, through a variety of potential processes. Developmental cascades in an individual refer to spreading effects resulting from interactions when they result in developmental changes in the person (Masten \& Cicchetti, 2010). 
Disasters can trigger many kinds of negative cascades, for example, when flooding leads to homelessness and then enduring poverty, or a tornado destroys a school, displacing all the children and injuring some of them, which then leads to post-traumatic stress and later school attendance issues. The cascading negative consequences of COVID-19 are readily observable. Contagion is a striking example of a negative cascade as infection spreads from one person to another, one family to another, and one country to another. The catastrophic effects of rapid spread for survival in the case of a serious disease is illustrated by the limited surge capacity of medical centers to treat seriously ill patients. Efforts to contain the virus have triggered a multiplying negative cascade of social and economic consequences at multiple levels.

Positive changes also can cascade across systems. Brain development can lead to better decision-making and selfregulation and many efforts to promote resilience among children at risk are intended to produce a positive cascade (Masten \& Cicchetti, 2010, 2016). A growing literature on the spreading effects of early interventions, such as home visiting nurses or high-quality preschool, illustrates positive cascades as early investments lead to later successes in life (Yoshikawa et al., 2020). Doty et al. (2017) have delineated a conceptual model of positive resilience cascades in families, articulated in the context of preventive interventions to promote better parenting. The explicit or implicit goal of many parenting interventions is to trigger a positive cascade in the family through changing parent behavior as a key lever (Masten \& Palmer, 2019). There is growing interest in empirical studies of naturally occurring cascades and interventions to promote positive cascades in the aftermath of disaster (Brown et al., 2017; Masten et al., 2015; Newman et al., 2014; Osofsky \& Osofsky, 2018).

Disasters and responses to disaster can initiate positive as well as negative cascading effects. For a contagious pathogen, social distancing and preventive measures such as handwashing and masks worn by individuals can reduce the likelihood of a community exceeding its medical response capacity. Government leaders and public health officials may suggest or demand these measures, but they are implemented at the family and individual level with cascading consequences for hospitals and population survival.

Vaccination against a dangerous infectious agent is the classic example of a protective factor that works by mobilizing and improving the defenses of individuals to the benefit of entire communities. Successful vaccines boost the resilience of the individual immune system to a pathogen and that individual effect in turn, when implemented on a "herd immunity" scale, can protect entire communities and regions (Metcalf et al., 2015).

It is important to note that the behaviors of individuals, families, and communities are interdependent with respect to resilience in disasters as in other kinds of threats. Many of the risk and protective factors for children in the context of disasters, including this pandemic, rely on the collective impacts of the behavior of their families, communities, and governments.

\section{What Matters for Child Well-being in the Context of Disasters?}

Most studies of disaster effects on children have observed dose gradients and cumulative effects of trauma, where children who are exposed to more adverse events or more intense devastation, loss, or disruption show stronger reactions as do children who have past or ongoing histories of adversity (Masten et al., 2015; Pfefferbaum et al., 2013). Preventing added exposure and mitigating ongoing exposure to adversity whenever possible is vital in disaster response, including exposure via media. Yet, extremely disadvantaged families may already carry the cumulative consequences of chronic and even multigenerational trauma or oppression; they confront the new challenges of a pandemic or a hurricane with more vulnerabilities and fewer resources and protective factors to defend against increasing threats and stress caused by cascading disasters.

In terms of COVID-19, there is good reason to be concerned about children who were already struggling with the risks and developmental harms associated with poverty, racism, neglect, food insecurity, homelessness, violence or chaos in the home, or inadequate healthcare. These children are now more isolated and may well have parents under even greater stress. Their homes and families may lack the resources to deal with distance learning or working from home, much less the added burdens posed by a potentially life-threatening infection, unemployment, and having children at home all the time. These children and their families need extraordinary support from their communities, schools, governments, and humanitarian agencies to meet the acute challenges of a pandemic in the context of chronic adversity and deprivation.

Developmental timing of disaster also matters in complex ways (Masten \& Osofsky, 2010; Masten et al., 2015; Yoshikawa et al., 2020). For example, younger children may not apprehend the scope of the destruction nor the implications for the future whereas older children and youth may be all too aware of the damage. Older children are out and about more in the community on their own where they can observe disaster effects. Younger children may be protected by lack of awareness, but they are highly vulnerable to separations or loss of caregivers. Early childhood also is a sensitive period for brain development and learning. Older children have stronger ties to friends outside the family and thus have more to lose when friends are harmed or lost. On the other hand, older children and adolescents have more human and social capital in general than young children. They have more advanced neural and cognitive functioning as a result of brain 
development and experience. Many of the protective/adaptive skills described in the next section are influenced by the maturation of human brain function and related capacities for selfregulation, problem-solving, and planning. Children and youth also gradually gain knowledge about what to do in the face of challenges from many smaller challenges in the normal course of life.

Disaster effects also can vary by the timing in relation to family development in the family life cycle (Walsh, 2016). The COVID-19 pandemic poses different challenges to families with no children, very young children, school-age children, college-aged children, or aging parents, as well as different family constellations (e.g., multigenerational versus single-parent households). Many parents in the pandemic are struggling with work-life balance issues and the suspension of key family supports, such as daycare or school, or the return home due to safety concerns or unemployment of aging parents or young adult children.

Narrative and the rare systematic reviews in the resilience literature on children and youth have consistently implicated a recurring set of factors associated with more positive adaptation in the context of diverse kinds of adversity exposure, including disaster (Gartland et al., 2017; Masten, 2014b; Wright et al., 2013; Masten, et al., 2015; Meng et al., 2018). For children, these include close relationships, psychological skills and capacities, and community-based supports.

When individual children are the focus of study, the quality of the parent-child relationships, parent management skills, or family cohesion are frequently identified as protective factors (e.g., Masten \& Palmer, 2019; Meng et al., 2018). From this perspective, effects of family functioning represent contextual protective influences (Harrist et al., 2019). However, in studies of family resilience, the family unit as a whole is the system of focus. At this level of analysis, too, multiple resilience factors or qualities have been identified. Family resilience factors based on family system theory reflect family dynamics that protect the functions of the family as a whole while caring for individual family members. Protective factors and processes identified at the child and family level show striking alignment (Masten, 2018a). We believe that this symmetry extends to other systems, including schools and communities.

Table 1 presents a list of broad resilience factors widely observed in the literature concerned with children, youth, and families with expected parallels that might be hypothesized to emerge in systematic reviews of resilience at the school and community level. We believe that widely cited theory and narrative reviews of resilience support this speculation, but additional corroborating evidence is needed (see Berkes \& Ross, 2013; Dwiningrum, 2017; Masten, 2018b; Norris et al., 2008; Ungar et al., 2019; Vogel \& Pfefferbaum, 2014).

Assuming the alignment indicated by this table has merit, it begs the question: Why do these adaptive factors and processes align so well? We suggest that these factors reflect fundamental human adaptive systems that have evolved over time and generations of human evolution, biological and cultural, and that they co-evolved at multiple levels of human psychosocial function in key contexts of human interaction. The first author (Masten, 2001, 2014b) suggested the same basic idea to explain the "shortlist" of common resilience factors consistently found in research on protective factors in studies of children and youth. However, there is a growing consensus that resilience reflects complex adaptive systems and processes that engage networks of systems at multiple levels (Ioannidis et al., 2020; Masten, in press; Ungar, 2018; Ungar \& Theron, 2020). We propose that resilience processes reflected in Table 1 parallel so well because that is the way they evolved and actually operate in the world, as layers of interacting or embedded systems or networks that shape individual and social adaptation and development in human lives.

These resilience factors provide a guide to major psychosocial drivers of resilience that can be mobilized or restored to protect the well-being children or foster recovery in the context of many different kinds of adversities, including disasters. However, it should be noted that this table does not include biological protective factors, such as overall health, immune function, or neurobiological stress regulation or protective factors embedded in governments, economic systems, cultures, including religion, or many other social-ecological systems, nor the protections afforded by financial and material resources. Moreover, communities operate systems that provide clean water, safety, electricity, healthcare, transportation, emergency services, education, and many other services that sustain community function and support families.

While culture is not explicitly included in Table 1, culture infuses every level of resilience (Masten, 2014b; Ungar, 2011; Ungar et al., 2013). Human lives and development are deeply embedded in layers of cultural context that influence caregiving, socialization, education, nutrition, identity, family traditions, religious or spiritual practices, values, beliefs, and many other aspects of life. Cultural systems, including religion as well as ethnic traditions, provide many of the guidelines for raising children and traditions or rituals for dealing with adversities (MottiStefanidi, 2018). Crawford et al. (2006), in their article on resilience and spirituality in youth, suggested that religions nurture and support very similar resilience factors to those listed in Table 1. These include close relationships (spiritual and human), social support, self-regulation practices such as meditation or prayer, systems of belief that provide hope about the future and give life meaning and purpose, rituals that ease difficult transitions in life such as the loss of loved ones, and communities that provide a sense of belonging. 
Table 1 Parallel psychosocial resilience factors in human systems at the level of individual, family, school, and community

\begin{tabular}{|c|c|c|c|}
\hline Individual children or youth & Family & School & Community \\
\hline $\begin{array}{l}\text { Nurturing and sensitive } \\
\text { caregivers }\end{array}$ & $\begin{array}{l}\text { Nurturing by family, care of } \\
\text { vulnerable members }\end{array}$ & $\begin{array}{l}\text { Nurturing by school community, } \\
\text { disability services }\end{array}$ & $\begin{array}{l}\text { Social capital, care of vulnerable } \\
\text { members }\end{array}$ \\
\hline $\begin{array}{l}\text { Close relationships, trust, } \\
\text { belonging }\end{array}$ & $\begin{array}{l}\text { Close relationships, trust, belonging, } \\
\text { cohesion }\end{array}$ & $\begin{array}{l}\text { Close relationships, trust, belonging, } \\
\text { cohesion }\end{array}$ & $\begin{array}{l}\text { Social connections, trust, belonging, } \\
\text { cohesion }\end{array}$ \\
\hline $\begin{array}{l}\text { Self-regulation, executive } \\
\text { function skills }\end{array}$ & Skilled family management & Skilled school leadership & Skilled governance, collective efficacy \\
\hline Agency; active coping & Active coping & Active coping & Community action \\
\hline Problem-solving and planning & Family problem-solving and planning & $\begin{array}{l}\text { School problem-solving and plan- } \\
\text { ning }\end{array}$ & $\begin{array}{l}\text { Collaborative community } \\
\text { problem-solving, planning }\end{array}$ \\
\hline Hope, optimism & Hope, optimism & Hope, optimism & Hope, optimism \\
\hline $\begin{array}{l}\text { Sense of individual meaning } \\
\text { and purpose }\end{array}$ & $\begin{array}{l}\text { Sense of family meaning, purpose, } \\
\text { family coherence }\end{array}$ & $\begin{array}{l}\text { Sense of school meaning, purpose, } \\
\text { and coherence }\end{array}$ & $\begin{array}{l}\text { Sense of community meaning, purpose, } \\
\text { and coherence }\end{array}$ \\
\hline $\begin{array}{l}\text { Positive views of self, } \\
\text { self-efficacy }\end{array}$ & Positive views of family & Positive views of school & Positive views of community \\
\hline Positive habits, routines & $\begin{array}{l}\text { Family routines, traditions, } \\
\text { celebrations }\end{array}$ & $\begin{array}{l}\text { School routines, traditions, } \\
\text { celebrations }\end{array}$ & $\begin{array}{l}\text { Community routines, traditions, } \\
\text { celebrations }\end{array}$ \\
\hline
\end{tabular}

\section{Implications of a Developmental Multisystem Resilience Framework in Disaster}

What are the implications of a multisystem resilience perspective for actions to promote the resilience of children and youth before, during, and after disaster? A comprehensive answer is well beyond the scope of this commentary and implications also will vary as a function of disaster parameters. Our comments here are intended to highlight how a resilience lens may contribute to this critically important question.

It is essential in disaster preparedness that the specific needs and issues of children at multiple system levels are included in planning and training (Danese et al., 2020; Masten et al., 2015; Peek et al., 2018; Wisner et al., 2018). Examples include medical supplies suitable for all ages of children and personnel trained to handle medical needs of children; emergency response plans that consider the issues and needs posed by separated families, children with disabilities, groups of children stranded in daycare or schools, and traumatized children. First responders need to understand how children of different ages show trauma and how they may react to separation from their families. Administrators need to understand that first responders are not likely to do an optimal job if the safety of their own children is unknown or threatened. Plans for reuniting families are essential and resilience at multiple levels will be facilitated by normalizing opportunities for children to play, learn, and contribute to recovery in ways suited to their development and skills.

Parents need support to foster the resilience of their families and their children as well as their communities in their roles as workers and citizens. Both parents and news media must consider the impact of media reports of disaster on children in order to plan accordingly. More generally, plans are needed at all system levels for communicating with children and families in disasters (Wisner et al., 2018). Communities and governments can support families through planning in advance for sustaining or restoring safe housing, clean water, adequate nutrition and healthcare, the capacity to work for adults, daycare and school for children, and supporting cultural practices that provide social, emotional, and spiritual support to community members.

The COVID-19 pandemic has posed particular challenges for children, families, schools, and communities because it represents a rare kind of global disaster that many systems were unprepared to confront. While children have, to date, proven to be less susceptible to becoming ill from this novel pathogen, their lives have been dramatically disrupted by school closures, shelter-at-home orders, and other social distancing efforts to contain the rate of infection. Some children have lost family members but many more have lost the normal routines of school, play, social life, vacations, and celebrations marking developmental milestones, such as graduation. There are many signs of frustration and distress, but also observable signs of resilience emerging.

Families, schools, communities, and young people themselves are responding with diverse and creative efforts to learn, teach, play, work, and connect in meaningful ways at a distance. Many organizations have produced video and written advice to parents about how to communicate with children about the coronavirus and when to seek extra help. The remarkably creative team at Sesame Workshop has produced special shows for children and families about the coronavirus and created a web-based set of resources to support families during the COVID-19 crisis, called "Caring for Each Other." Older children and adolescents keep in touch with their friends through social media. Teachers drive by to wave at their 
students or leave chalk messages on their driveways. Graduation ceremonies are held in parades, in parks, or on speedways with graduates in separate cars.

Each disaster experience holds lessons for future resilience planning at multiple system levels. Hurricane Katrina revealed gaps in emergency and recovery planning for children as did the complex triple disaster of the 2011 earthquake, tsunami, and radiation disaster it triggered with the meltdown of the Fukushima Daiichi nuclear facility (Masten et al., 2015; Osofsky \& Osofky, 2018; Reckdahl, 2015). COVID-19 undoubtedly will bring many lessons as well to improve disaster readiness. This disaster has cast a bright light on the costs during a pandemic of inequality in access to healthcare and resources for individuals, families, communities, and whole societies. Children should not need to rely on schools to have adequate food. It also is clear that all school-aged children need access to the internet and the tools and skills for learning online, while educators at every level need more training in how to engage students and teach effectively online.

In some disasters, communities learn that schools need to be strengthened through structural means or training drills to prepare for earthquakes, wildfires, tornadoes, or terror attacks. In this disaster, communities are learning that their schools are not built or structured for the kind of flexibility needed for social distancing and other necessary requirements for protecting against the dangers of a contagious pathogen. Built environments, organizational structures, routines, rules, and schedules of schools may need to transform in the face of this challenge. In addition, this pandemic has underscored the essential roles of childcare and school systems for everyone in communities to function normally.

In the aftermath of disaster, it is important to restore a sense of safety and normalcy. For very young children, the sensitive care of parents and other caregivers and basic routines of daily life in the family can provide the essential safety and sense of normalcy. For older children and youth, the challenge can be far greater because their lives are embedded in many more systems of childcare, school, friendships, work opportunities, and recreational activities that can be much more difficult to restore. As children grow older, they also begin to understand the broader scope of impacts a disaster can bring. Adolescents are well aware that their future opportunities have been altered by a disaster. Thus, for older children and youth, it is crucial to restore hope and pathways of opportunity as well as school routines or social life.

Engaging youth in recovery planning and actions to prepare for future disasters can build that sense of hope for the future as well as immediate feelings of self-efficacy and agency with the potential to counter feelings of helplessness that can accompany the experience of disaster (Masten et al., 2015; Osofsky et al., 2018). The Federal Emergency Management Administration (FEMA) created a Youth Preparedness Council in 2012 of teenagers in grades 8 to 11 who provide youth perspectives to FEMA and support disaster preparedness in their communities. FEMA also includes a section in the Ready Kids program on teen leadership in disasters; teens can volunteer for training in disaster preparedness and community response in a program called "Teen CERT" (Community Emergency Response Team). The Sendai Framework for Disaster Risk Reduction (United Nations Office for Disaster Risk Reduction, 2015) endorsed the concept of children as "agents of change" who should be accorded ways to participate in disaster risk reduction (p. 23). Gibbs et al. (2017) describe this approach as engaging the "citizen child" in disaster response. The Youth Leadership Program described by Osofsky et al. (2018) provides an example in a school context following Hurricane Katrina. We assume this kind of intervention with its empowerment of youth engages and reinforces the powerful adaptive systems variously referred to as agency or mastery motivation, self-efficacy, active coping, hope or optimism, and purpose or meaning.

In the case of the COVID-19 pandemic, youth can be engaged in multiple ways. Teen volunteers from FEMA's CERT program have engaged in a variety of volunteer activities to help with the COVID response across the country, such as testing site support (Federal Emergency Management Agency, 2020).

Youth can be engaged to help with short-term plans for resuming school, recreational activities, and community celebrations. However, they also could be enlisted to prepare for future disasters likely in their region or new waves of infection. The present pandemic may be a wake-up call for communities to prepare for the accelerating disasters associated with climate change (Paton \& Johnston, 2017; Stott, 2016; Van Lange et al., 2018). Youth can play a key leadership role in preparing for climate-related and other future disasters.

\section{Conclusion}

Promoting resilience in disaster is a multisystem challenge, requiring the collaboration and insights of people in many systems and disciplines. Bolstering or restoring key adaptive systems implicated in multiple disciplines on resilience is central, informed by the growing knowledge base on resilience in different systems. However, much more focus is needed on the processes that connect systems and foster positive multisystem cascades of resilience. Integrating and applying the knowledge from different disciplines and systems are going to require not only expertise from many disciplines and sectors, as well as funding, but also informed leadership and teams of responders with the skills and mindsets needed to communicate, cooperate, and coordinate efforts across sectors and levels. Multisystem preparation and effective responses in the context of disasters call for coordinated expertise and 
cooperation that is likely to require multisystem training and planning at local, state, national, and global levels.

The resilience of children in disasters depends on many systems and adaptive capacities within the child, in relationships with caregivers, families, or friends, and in resources and capacities provided by families, schools, and communities. Each of those systems depends on other systems and resources as well as internal capabilities. Disasters can overwhelm many of the systems that children and families depend on, either simultaneously or in a devastating cascade of challenges. However, disasters also mobilize responses across many systems and motivate better responses in the future. COVID-19 is uncovering many gaps in how well many communities are prepared to meet the needs of children and families in this pandemic as well as the cost to collective resilience of health and socioeconomic disparities. It is imperative to respond now to the pandemic disaster with the best knowledge available on what matters for children and what works to protect them. However, it also is crucial to learn as much as possible from this disaster to prepare for future shocks, both expected and unknown.

\section{Code Availability NA}

Funding Information Preparation of this article was supported in part by the Irving B. Harris Professorship in Child Development (Masten).

Data Availability NA

\section{Compliance with Ethical Standards}

Conflict of Interest The authors declare that they have no conflict of interest.

\section{References}

Aldrich, D. P. (2012). Building resilience: Social capital in post-disaster recovery. University of Chicago Press.

Berkes, F., \& Ross, H. (2013). Community resilience: Toward an integrated approach. Society \& Natural Resources: An International Journal, 16(1), 5-20. https://doi.org/10.1080/08941920.2012. 736605.

Becvar, D. S. (Ed.). (2013). Handbook of family resilience. New York: Springer.

Betancourt, T. S., Meyers-Ohki, S. E., Charrow, A., \& Hansen, N. (2013). Annual research review: Mental health and resilience in HIV/AIDS-affected children-a review of the literature and recommendations for future research. Journal of Child Psychology and Psychiatry, 54(4), 423-444. https://doi.org/10.1111/j.1469-7610. 2012.02613.x.

Bronfenbrenner, U., \& Morris, P. A. (2006). The bioecologival model of human development. In R. M. Lerner \& W. Damon (Eds.), Handbook of child psychology: Theoretical models of human development (pp. 793-828). John Wiley \& Sons Inc.

Brown, R. C., Witt, A., Fegert, M., Keller, F., Rassenhofer, M., \& Plener, P. L. (2017). Psychosocial interventions for children and adolescents after man-made and natural disasters: A meta-analysis and systematic review. Psychological Medicine, 47(11), 1893-1905. https://doi.org/10.1017/S0033291717000496.

Catani, C., Jacob, N., Schauer, E., Kohila, M., \& Neuner, F. (2008). Family violence, war, and natural disasters: A study of the effect of extreme stress on children's mental health in Sri Lanka. BMC Psychiatry, 8, Article 33. https://doi.org/10.1186/1471-244X-8-33.

Comas-Díaz, L., Hall, G. N., \& Neville, H. A. (2019). Racial trauma: Theory, research, and healing: Introduction to the special issue. American Psychologist, 74(1), 1-5. https://doi.org/10.1037/ amp0000442.

Crawford, E., Wright, M. O’D., \& Masten, A. S. (2006). Resilience and spirituality in youth. In E. C. Roehlkepartain, P. E. King, L. Wagener, \& P. L. Benson, (Eds.), The handbook of spiritual development in childhood and adolescence (pp. 355-370). Sage Publications Inc.

Danese, A., Smith, P., Chitsabesan, P., \& Dubicka, B. (2020). Child and adolescent mental health amidst emergencies and disasters. The British Journal of Psychiatry, 216(3), 159-162. https://doi.org/10. 1192/bjp.2019.244.

Despert, J. L. (1944). Effects of war on children's mental health. Journal of Consulting Psychololgy, 8(4), 206-218. https://doi.org/10.1037/ h0054103.

Doty, J. L., Davis, L., \& Arditti, J. A. (2017). Cascading resilience: Leverage points in promoting parent and child well-being. Journal of Family Theory \& Review, 9(1), 111-126. https://doi.org/10.1111/ jftr.12175.

Dwiningrum, S. I. A. (2017). Developing school resilience for disaster mitigation: A confirmatory factor analysis. Disaster Prevention and Management, 26(4), 437-451. https://doi.org/10.1108/DPM-022017-0042.

Erikson, K. T. (1976). Everything in its path: Destruction of community in the Buffalo Creek flood. Simon \& Schuster.

Fauci, A. S., \& Eisinger, R. W. (2018). PEPFAR-15 years and counting the lives saved. The New England Journal of Medicine, 378, 314 416. https://doi.org/10.1056/NEJMp1714773.

Federal Emergency Management Agency (2020, May). CERT volunteers on COVID-19 front lines. U.S. Department of Homeland Security, Federal Emergency Management Agency. https://community.fema. gov/story/CERT-Volunteers-on-COVID-19-Front-Lines?lang=en US.

Fothergill, A. (2017). Children, youth, and disaster. Oxford Research Encyclopedia of Natural Hazard Science. Oxford University Press. https://doi.org/10.1093/acrefore/9780199389407.013.23.

Freud, A., \& Burlingham, D. T. (1943). War and children. Medical War Books.

Furr, J. M., Comer, J. S., Edmunds, J. M., \& Kendall, P. C. (2010). Disasters and youth: A meta-analytic examination of posttraumatic stress. Journal of Consulting and Clinical Psychology, 78(6), 765 780. https://doi.org/10.1037/a0021482.

Garmezy, N. (1983). Stressors of childhood. In N. Garmezy \& M. Rutter (Eds.), Stress, coping, and development. (pp. 43-84). Johns Hopkins University Press.

Gartland, D., Riggs, E., Muyeen, S., Giallo, R., Afifi, T. O., MacMillan, H., Herrman, H., Bulford, E., \& Brown, S. J. (2017). What factors are associated with resilient outcomes in children exposed to social adversity? A systematic review. BMJ Open, 9, Article 9:e024870. https://doi.org/10.1136/bmjopen-2018-024870.

Gibbs, L., Macdougall, C., Mutch, C., \& O’Connor, P. (2017). Child citizenship in disaster risk and affected environments. In D. Paton \& D. Johnson (Eds.), Disaster resilience: An integrated approach ( $2^{\text {nd }}$ ed., pp. 138-157). Charles C Thomas.

Gleser, G., Green, B., \& Winget, C. (1981). Prolonged psychological effects of disaster: A study of Buffalo Creek. Academic Press.

Gottlieb, G. (2007). Probabilistic epigenesis. Developmental Science, 10(1), 1-11. https://doi.org/10.1111/j.1467-7687.2007.00556.x. 
Harrist, A. W., Henry, C. S., Liu, C., \& Morris, A. S. (2019). Family resilience: The power of rituals and routines in family adaptive systems. In B. H. Fiese, M. Celano, K. Deter-Deckard, E. N. Jouriles, \& M. A. Whisman (Eds.), APA handbook of contemporary family psychology: Foundations, methods, and contemporary issues across the lifespan (pp. 223-239). American Psychological Association.

Henry, C. S., Morris, A. S., \& Harrist, A. W. (2015). Family resilience: Moving into the third wave. Family Relations, 64(1), 22-43. https:// doi.org/10.1111/fare.12106.

Ioannidis, K., Askelund, A. D., Kievit, R. A., \& van Harmelen, A. L. (2020). The complex neurobiology of resilient functioning after childhood maltreatment. BMC Medicine, 18, Article 32. https:// doi.org/10.1186/s12916-020-1490-7.

Kalisch, R., Cramer, A. O. J., Binder, H., Fritz, j., Leerouwer, I., Lunansky, G., Meyer, B., timmer, J., Veer, I. M., \& van Harmelen, A.-L. (2019). Deconstructing and reconstructing resilience: A dynamic network approach. Perspectives on Psychological Science, 14(5), 765-777. https://doi.org/10.1177/ 1745691619855637.

Korol, M., Kramer, T. L., Grace, M. C., \& Green, B. L. (2002). Dam break: Long-term follow-up of children exposed to the Buffalo Creek disaster. In A. M. La Greca, W. K. Silverman, E. M. Vernberg, \& M. C. Roberts (Eds.), Helping Children Cope with Disasters and Terrorism. (pp. 241-257). American Psychological Association.

Lacey, G. N. (1972). Observations on Aberfan. Journal of Psychosomatic Research, 16(4), 257-260. https://doi.org/10.1016/0022-3999(72) 90007-4.

La Greca, A. M., \& Silverman, W. K. (2009). Treatment and prevention of posttraumatic stress reactions in children and adolescents exposed to disasters and terrorism: What is the evidence? Child Development Perspectives, 3(1), 4-10. https://doi.org/10.1111/j.1750-8606.2008. 00069.x.

Lai, B. S., Esnard, A., Lowe, S. R., \& Peek, L. (2016). Schools and disasters: Safety and mental health assessment and interventions for children. Current Psychiatry Reports, 18(12), 1-9. https://doi. org/10.1007/s11920-016-0743-9.

Lerner, R. M. (2006). Developmental science, developmental systems, and contemporary theories of human development. In R. M. Lerner (Vol. Ed.) \& W. Damon \& R. M. Lerner (Eds.), Handbook of child psychology: Vol. 1. Theoretical models of human development $\left(6^{\text {th }}\right.$ ed., pp. 1-17). John Wiley \& Sons Inc.

Masten, A. S. (2001). Ordinary magic: Resilience processes in development. American Psychologist, 56(3), 227-238. https://doi.org/10. 1037/0003-066X.56.3.227.

Masten, A. S. (2014a). Global perspectives on resilience in children and youth. Child Development, 85(1), 6-20. https://doi.org/10.1111/ cdev.12205.

Masten, A. S. (2014b). Ordinary magic: Resilience in development. Guilford Press.

Masten, A. S. (2018a). Resilience theory and research on children and families: Past, present, and promise. Journal of Family Theory and Review, 10(1), 12-31. https://doi.org/10.1111/jttr.12255.

Masten, A. S. (2018b). Schools nurture resilience of children and societies. Green Schools Catalyst Quarterly, V(3), 14-19.

Masten, A. S. (in press). Resilience in developmental systems: Principles, pathways, and protective processes in research and practice. In M. Ungar \& M. (Eds.), Multisystemic resilience: Adaptation and transformation in changing contexts. Oxford University Press.

Masten, A. S., \& Cicchetti, D. (2010). Editorial: Developmental cascades. [Special Issue on Developmental Cascades, Part 1], Development and Psychopathology, 22(3), 491-495. https://doi.org/10.1017/ S0954579410000222.

Masten, A. S., \& Cicchetti, D. (2016). Resilience in development: Progress and transformation. In D. Cicchetti (Ed.), Developmental psychopathology, vol. 4: Risk, resilience, and intervention $\left(3^{\text {rd }} \mathrm{ed}\right.$, pp. 271-333). John Wiley \& Sons Inc. https://doi.org/10.1002/ 9781119125556.devpsy406.

Masten, A. S., \& Monn, A. R. (2015). Child and family resilience: A call for integrated science, practice, and professional training. Family Relations: An Interdisciplinary Journal of Applied Family Studies, 64(1), 5-21. https://doi.org/10.1111/fare.12103.

Masten, A. S., \& Motti-Stefanidi, F. (2009). Understanding and promoting resilience in children: Promotive and protective processes in schools. In T. B. Gutkin \& C. R. Reynolds (Eds.), The handbook of school psychology (4 ${ }^{\text {th }}$ ed., pp. 721-738). John Wiley \& Sons Inc.

Masten, A., Motti-Stefanidi, F., \& Rahl-Brigman, H. (2019). Developmental risk and resilience in the context of devastation and forced migration. In R. Parke \& G. Elder, Jr. (Eds.), Children in changing worlds: Sociocultural and temporal perspectives (pp. 84-111). Cambridge University Press. https://doi.org/10.1017/ 9781108264846.004.

Masten, A. S., \& Narayan, A. J. (2012). Child development in the context of disaster, war and terrorism: Pathways of risk and resilience. Annual Review of Psychology, 63, 227-257. https://doi.org/10. 1146/annurev-psych-120710-100356.

Masten, A. S., Narayan, A. J., Silverman, W. K., \& Osofsky, J. D. (2015). Children in war and disaster. In M. H. Bornstein, T. Leventhal, \& R. M. Lerner (Eds.), Handbook of child psychology and developmental science: Ecological settings and processes in developmental systems $\left(7^{\text {th }}\right.$ ed., pp. 704-745). John Wiley \& Sons Inc.

Masten, A. S., \& Osofsky, J. D. (2010). Disasters and their impact on child development: Introduction to the special section. Child Development, 81(4), 1029-1039. https://doi.org/10.1111/j.14678624.2010.01452.x.

Masten, A. S, \& Palmer, A. R. (2019). Parenting to promote resilience in children. In M. H. Bornstein (Ed.), Handbook of Parenting ( $3^{\text {rd }}$ ed., 156-188). Routledge.

Meng, X., Fleury, J.-J., Xiaang, Y.-T., Li, M., \& D’Arcy, C. (2018). Resilience and protective factors among people with a history of child maltreatment: A systematic review. Social Psychiatry and Psychiatric Epidemiology, 53, 453-475. https://doi.org/10.1007/ s00127-018-1485-2.

Metcalf, C. J. E., Ferrari, M., Graham, A. L., \& Grenfell, B. T. (2015). Understanding herd immunity. Trends in Immunology, 36(12), 753755. https://doi.org/10.1016/j.it.2015.10.004.

Motti-Stefanidi, F. (2018). Resilience among immigrant youth: The role of culture, development and acculturation. Developmental Review, 50, 99-109. https://doi.org/10.1016/j.dr.2018.04.002.

Newman, E., Pfefferbaum, Kirlic, N., Tett, R. Nelson, S., \& Liles, B. (2014). Meta-analytic review of psychological interventions for children survivors of natural and man-made disasters. Current Psychiatry Reports, 16, Article 462. https://doi.org/10.1007/ s11920-014-0462-z.

Norris, F. H., Stevens, S. P., Pfefferbaum, B., Wyche, K. F., \& Pfefferbaum, R. L. (2008). Community resilience as a metaphor, theory, set of capacities, and strategy for disaster readiness. American Journal of Community Psychology, 41(1-2), 127-150. https://doi.org/10.1007/s10464-007-9156-6.

Osofsky, J. D., \& Osofsky, H. J. (2018). International perspectives on young children and disasters. Zero to Three, 38(4), 57-60.

Osofsky, H. J., Osofsky, J. D., Hansel, T., Lawrason, B., \& Speier, A. (2018). Building resilience after disasters through the Youth Leadership Program: The importance of community and academic partnerships on youth outcomes. Progress in Community Health Partnerships: Research, Education, and Action, 12(1), 11-21. https://doi.org/10.1353/cpr.2018.0017.

Overton, W. F. (2013). A new paradigm for developmental science: Relationism and relational-developmental systems. Applied Developmental Science, 17(2), 94-107. https://doi.org/10.1080/ 10888691.2013.778717. 
Paton, D., \& Johnston, D. (2017). Disaster resilience: An integrated approach (2nd ed.) Charles C Thomas.

Peek, L., Abramson, D. M., Cox, R. S., Fothergill, A., \& Tobin, J. (2018). ( $2^{\text {nd }}$ ed.). Children and disasters. In H. Rodrigues, W. Donner, \& J. E. Trainor (Eds.), Handbook of disaster research (243-262). Springer. https://doi.org/10.1007/978-3-319-63254-4_13.

Pfefferbaum, B., Weems, C. F., Scott, B. G., Nitiéma, P., Noffsinger, M. A., Pfefferbaum, R. L., Varma, V., \& Chakraburtty, A. (2013). Research methods in child disaster studies: A review of studies generated by the September 11, 2001, terrorist attacks; the 2004 Indian Ocean tsunami; and Hurricane Katrina. Child \& Youth Care Forum, 42, 285-337. https://doi.org/10.1007/s10566-0139211-4.

Reckdahl, K. (2015). The lost children of Katrina. The Atlantic. https:// www.theatlantic.com/education/archive/2015/04/the-lost-childrenof-katrina/389345/.

Reifels, L., Spittal, M. J., Dückers, M. L. A., Mills, K., \& Pirkis, J. (2018). Suicidality risk and (repeat) disaster exposure: Findings from a nationally representative population survey. Psychiatry, 81(2), 158172. https://doi.org/10.1080/00332747.2017.1385049.

Sayward, H., Li, X., \& Vermund, S. H. (2019). From surviving to thriving: The role of resilience in meeting global HIV goals. AIDS, 33, S1-S4. https://doi.org/10.1097/QAD.0000000000002242.

Seddighi, H., Salmani, I., Javadi, M. H., \& Seddighi, S. (2019). Child abuse in natural disasters and conflicts: A systematic review. Trauma, Violence \& Abuse, 1-10. https://doi.org/10.1177/ 1524838019835973.

Sherr, L., Cluver, L. D., Betancourt, T. S., Kellerman, S. E., Richter, L. M., \& Desmond, C. (2014). Evidence of impact: Health, psychological and social effects of adult HIV on children. AIDS, 28(3), S251S259. https://doi.org/10.1097/QAD.0000000000000327.

Sherr, L., Skeen, S., Hensels, I. S., Tomlinson, M., \& Macedo, A. (2016). The effects of caregiver and household HIV on child development: A community-based longitudinal study of young children. Child: Care, Health and Development, 42(6), 890-899. https://doi.org/10. $1111 /$ cch.12387.

Stott, P. (2016). How climate change affects extreme weather events. Science, 352(6293), 1517-1518. https://doi.org/10.1126/science. aaf7271.

UNAIDS (2019). Fact sheet-World AIDS day 2019. United Nations Economic and Social Counsel, The Joint United Nations Programme on HIV/AIDS. https://www.unaids.org/sites/default/ files/media_asset/UNAIDS_FactSheet_en.pdf.

Ungar, M. (2011). The social ecology of resilience: Addressing contextual and cultural ambiguity of a nascent construct. American Journal of Orthopsychiatry, 81(1), 1-17. https://doi.org/10.1111/j.19390025.2010.01067.x.

Ungar, M. (2018). Systemic resilience: Principles and processes for a science of change in contexts of adversity. Ecology and Society, 23(4), Article 34. https://doi.org/10.5751/ES-10385-230434.
Ungar, M., Connelly, G., Liebenberg, L., \& Theron, L. (2019). How schools enhance the development of young people's resilience. Social Indicators Research, 145, 615-627. https://doi.org/10.1007/ s11205-017-1728-8.

Ungar, M., Ghazinour, M., \& Richter, J. (2013). Annual research review: What is resilience within the social ecology of human development? Journal of Child Psychology and Psychiatry, 54(4), 348-366. https://doi.org/10.1111/jcpp.12025.

Ungar, M., \& Theron, L. (2020). Resilience and mental health: How multisystemic processes contribute to positive outcomes. The Lancet Psychiatry, 7(5), 441-448. https://doi.org/10.1016/S22150366(19)30434-1.

United Nations Office for Disaster Risk Reduction (2015). Sendai framework for disaster risk reduction 2015-2030. International Strategy for Disaster Reduction, United Nations Office for Disaster Risk Reduction. https://www.undrr.org/publication/sendai-frameworkdisaster-risk-reduction-2015-2030.

Van Lange, P. A. M., Joireman, J., \& Milinski, M. (2018). Climate change: What psychology can offer in terms of insights and solutions. Current Directions in Psychological Science, 27(4), 269-274. https://doi.org/10.1177/0963721417753945.

Vogel, J. M., \& Pfefferbaum, B. (2014). Family resilience after disasters and terrorism: Examining the concept. In R. Pat-Horenczyk, D. Brom, \& J. M. Vogel (Eds.), Helping children cope with trauma: Individual, family and community perspectives (pp. 81-100) Routledge/Taylor \& Francis Group.

Walsh, F. (2016). Strengthening family resilience (3rd ed.). New York: Guilford Press.

Webb Hooper, M., Nápoles, A. M., \& Pérez-Stable, E. J. (2020). COVID-19 and racial/ethnic disparities. Journal of the American Medical Association. https://doi.org/10.1001/jama.2020.8598.

Wisner, B., Paton, D., ALisic, E., Eastwood, O., Shreve, C., \& Fordham, M. (2018). Community with children and families about disaster: Reviewing multi-disciplinary literature 2015-2017. Current Psychiatry Reports, 20, Article73. https://doi.org/10.1007/s11920018-0942-7.

Wright, M. O’D., Masten, A. S., \& Narayan, A. J. (2013). Resilience processes in development: Four waves of research on positive adaptation in the context of adversity. In S. Goldstein \& R. B. Brooks, Handbook of resilience in children ( $2^{\text {nd }}$ ed., pp. 15-37). Springer. https://doi.org/10.1007/978-1-4614-3661-4_2.

Yoshikawa, H., Wuermli, A. J., Britto, P. R., Dreyer, B., Leckman, J. F., Lye, S. J., Ponguta, L. A., Richter, L. M., \& Stein, A. (2020). Effects of the global COVID-19 pandemic on early childhood development: Short- and long-term risks and mitigating program and policy actions. The Journal of Pediatrics. https://doi.org/10.1016/j.jpeds. 2020.05.020.

Zelazo, P. D. (2013). Developmental psychology: A new synthesis. In P. D. Zelazo (Ed.), The Oxford handbook of developmental psychology: Body and mind (pp. 3-12). Oxford University Press. https://doi. org/10.1093/oxfordhb/9780199958450.013.0001. 